Research Article

\title{
Traditional Games as Tourism Sports and Characteristics of Sports Culture in Sumbawa Indonesia
}

\author{
Demi Ade Maulana', ${ }^{1}$ Sugiyanto $^{2}$, Slamet Riyadi ${ }^{3}$ \\ ${ }^{123}$ Postgraduate in Sports Science, Sebelas Maret University, Indonesia
}

\begin{abstract}
This study aims to find out traditional games as tourism sports and characteristics of sport culture in sumbawa indonesia. This type of research is a qualitative research with a phenomenological approach. The informant retrieval technique uses the Snowball Sampling technique. Data collection techniques using observation, interviews, and document analysis. The data validity technique used triangulation technique. Data analysis was carried out in four stages, namely: the data collection stage, the data reduction stage, the data presentation stage, and the conclusion drawing stage. From the results of the study, it can be identified Sumbawa is an area rich in culture and tradition, there are many cultures and traditions. One example is in traditional games from the Sumbawa area such as: Barapan kebo, playing Jaran, Bakaraci, gentao, barempuk and so on. In each of these traditional games there is a culture and tradition in each game which is still maintained by the Sumbawa community itself until now. However, although there are many other traditional games, the popularity of the traditional game of Main Jaran is still very popular with the people of Sumbawa until now and is routinely carried out every year on the island of Sumbawa. It can be identified the sports values contained in the traditional game of playing jaran, namely: cooperation, communication, respect for rules, problem solving, understanding, relationships with others, leadership, respect for others, business values, how to achieve victory, respect defeat, how to manage competence, fair play, sharing, self-respect, trust, honesty, confidence, tolerance, and resilience. Ethical values such as fair play, honesty, and sportsmanship have special relevance in sports, where these values can be applied in increasing commitment to implementing fairness in competition.
\end{abstract}

Keywords: Traditional Games, Sport Tourism, Sport Culture

\section{Introduction}

Traditional games are one of the cultural relics of our ancestors that have the purity and style of local traditions (Widodo \& Lumintuarso, 2017). Indonesia is known to have a very diverse traditional cultural wealth (Syahputra et al., 2017). However, along with the rapid development of technology in this era of globalization, the wealth of traditional culture is increasingly sinking (Suprayitno, 2014).

The development of an increasingly rapid era as well as the development of science and technology has made it easier for humans in all things, even the impact of influencing changes in the field of play (Kamaludin et al., 2020). Children in modern times are identical with technological games that can be easily accessed through gadgets, for example via smartphones, tablets, computers, laptops and other technological devices (Danu Iksan, Sahputra Rachmat, 2013). Children tend to be more individual, less interactive with each other and preoccupied with their own world (Aqobah et al., 2020).

The game is a playing activity or sport that is played in accordance with applicable rules and is determined by ability, strength, or luck (Saputra \& Ekawati, 2017). Traditional comes from the Latin traditio, which means a habit that is passed down from generation to generation (Lingling et al., 2019). So the definition of traditional games when associated with these two definitions is a play activity that is passed down from generation to generation. According to research from the Jarahnitra Study Center, it is stated that traditional 


\section{Demi Ade Maulana et./al Traditional Games as Tourism Sports and Characteristics of Sports Culture in Sumbawa Indonesia}

folk games are cultural products of great value for children in the context of fantasy, recreation, creativity, exercise as well as a means of practicing for social life, skills, courtesy, and agility (Nurdiansyah, 2018).

In its implementation, traditional games can include elements of folk games and children's games into it. It is even possible to include activities that contain elements of art as commonly referred to as traditional art. An activity categorized as a traditional game must of course identify elements of tradition that are closely related to the habits or customs of a certain community group (Artobatama, 2019).

Many facts reveal that traditional games are superior in their influence on children's development when compared to modern games (Apriliawati \& Hartoto, 2016). Traditional games teach the importance of a process and insert good values also contain local wisdom that is very educational and provokes a sense of nationalism in children (Adi et al., 2020). In addition, although traditional games are simple games, they can provide extraordinary benefits such as training children in social life, especially with their peers, training dexterity, and developing children's motor skills (Hanief \& Sugito, 2015).Technological games prevent children from experiencing the process of a game, such as teaching how to cooperate with fellow friends, learning tolerance, understanding and forgiveness, stimulating motor development and cognitive (thinking) and affective (emotional) balance in children (Witasari \& Wiyani, 2020). Seeing this phenomenon, many efforts have been made to raise the prestige of traditional games through events such as cultural festivals, traditional games festivals and competitions related to traditional games (Supeni et al., 2020). There are even some individuals and social groups who specifically visit schools to introduce this traditional game (Hayati et al., 2017).

Culture can also be associated with sports (Nur \& Widiyatmoko, 2019). In today's developments, socioculture in sports is heavily influenced by social phenomena due to the dynamics of socio-cultural interactions in society (Burhaein, 2017). This is in line with its development, sport continues to develop in accordance with cultural developments. The socio-cultural basis of sport is the role of socio-cultural aspects related to sports or physical activities that are carried out daily (Martínez-Santos et al., 2020). As social beings, humans are part of the social system of society which in groups forms culture and traditions (Devrizal et al., 2019). Various kinds of arts and different cultural traditions that reflect the diversity of ethnic groups. In order to maintain local traditions and arts that have been deeply rooted in Indonesian society, it is important to carry out preservation considering the increasingly modern developments that have resulted in the erosion of traditions and arts so that it can be ascertained that these traditions and arts will gradually become extinct (Rahayu \& Firmansyah, 2019). To maintain and as a form of preservation of artistic traditions and cultural traditions, it is important to preserve Indonesian local traditions and arts (Wardika, 2019).

\section{Methods}

This type of research is a qualitative research with a phenomenological approach. The informant retrieval technique uses the Snowball Sampling technique. The subjects of this research are actors, connoisseurs and local community leaders who understand and know information about the traditional game of playing jaran. As for the number studied, namely community leaders and connoisseurs of playing jaran games then traditional game players are not limited in number because they are like snowball / snowball so to seek information related to the research it expands or enlarges depending on the phenomena encountered in the field and when it is deemed sufficient to get the results of research and can answer the formulation of the problem, the research is stopped (Iwandana et al., 2018). However, from the data in the field, the research subjects obtained are 3 community leaders, 20 people playing jaran game lovers, 10 traditional game players. Data collection techniques using observation, interviews, and document analysis. The data validity technique used triangulation technique. Data analysis was carried out in four stages, namely: the data collection stage, the data reduction stage, the data presentation stage, and the conclusion drawing stage.

\section{Results and Discussion}

\section{History of traditional event Sumbawa}

On the island of Sumbawa, West Nusa Tenggara is one of the regions in Indonesia that is rich in culture and tradition. Sumbawa is an island located in the province of West Nusa Tenggara, Indonesia. The island is 


\section{Demi Ade Maulana et./al Traditional Games as Tourism Sports and Characteristics of Sports Culture in Sumbawa Indonesia}

bounded by the Alas Strait to the west (separating from Lombok Island), the Sape Strait to the east (separating from Komodo Island), the Indian Ocean to the south, and the Flores Sea to the north.

Horse racing is a traditional event for the best sandros, jockeys and horses at the start of the rice planting season in Sumbawa and as a symbol of social status in culture for the Sumbawa people. The tradition of horse racing is not only held in Brang Kolong but also exists in Moyo Hulu Village, Senampar Village, Poto Village, Lengas Village, Batu Bangka Village, Maronge Village, Utan Village to Alas Village as a typical Sumbawa cultural event. This Sumbawa-style horse race is held during the rice planting season. An interesting characteristic of Sumbawa horse racing is the existence of Lawas horse racing or commonly referred to as ngumang which is a boast of victory as a charmer of women and spectators of horse racing and flirting with the lawas he controls when the horse race takes place. Karapan Kuda also contains a high philosophical meaning for a person's degree or prestige in the Sumbawa community, a symbol of honor, authority and a person's degree because the winner of a horse race in addition to receiving an award in the form of a certain prize, the winner will also receive an honorary title that makes him gain a valued social position. in the midst of society.

The culture of the Sumbawa people is a hereditary culture to this day. This culture still exists today, such as language and literature, tender arts ceremonies, horse racing, and horse competitions and so on. The Sumbawa horse is a local horse native to Indonesia which is a cross between a local horse and an Arabian horse or Thotoughbred (Sari, Arum, 2017).

The location or racetrack is in an arena that has been specially provided for holding horse racing in a dry area. The treatment of horse racing jargon owners is the same as the treatment of Main Jaran auditions. The participating horses were collected 3 or 4 days before this cultural event was held to measure their height and age. This is intended, so that it can be determined in what class the horses can be contested. The duration or duration of the event is determined by how much horse jargon participates in the Horse Racing cultural event.

This horse racing is an example of culture and entertainment for the Sumbawa people which has been carried out for generations. Horse racing was created to assist the Sumbawa community in interacting and communicating with other people. The interaction and communication that occurs through horse racing culture results in the formation of social groups. An interesting aspect of social groups is the way in which they control their members. The important thing about social groups is related to the forces that are interconnected and develop and have a role in regulating the actions of their members to achieve order for the good of the group. Social groups formed from interaction and communication between individuals or humans are based on kinship, age, sex, and sometimes on the basis of differences in work or position (Ashar Pajarungi Anar et al., 2020).

Membership of each of these social groups gives a certain position or prestige in accordance with the customs and social institutions in society. However, what is important is that membership in social groups is not always voluntary. Solidarity is a type of social order that views society as a different component and has a relationship with one another. Solidarity is divided into mechanical solidarity and organic solidarity (Nugrahastuti et al., 2012). Mechanical solidarity exists in rural communities, while organic solidarity occurs in urban communities. Mechanical solidarity is based on a shared collective consciousness that refers to the totality of beliefs and cultures. A society characterized by mechanical solidarity becomes one and cohesive, because all people are generalists.

\section{Main Jaran is a traditional game developed by the community around Sumbawa Regency}

Main Jaran is a traditional game developed by the community around Sumbawa Regency, West Nusa Tenggara, Indonesia. As the name implies, namely "jaran" or in Indonesian means "horse", in this game the participants will compete to control their horses in a racetrack. There are cultural values and traditions contained in the traditional game of playing jaran that are still maintained by the Sumbawa people to this day, in addition to the cultural values and traditions of playing jaran, it is also a place for entertainment for the Sumbawa people and also as a place to establish friendship and relationships friendship between the people of Sumbawa.

The game of playing jaran itself involves a jockey figure. That's where the attraction of playing jaran arena on Sumbawa Island. Jockeys or horse riders on the island of Sumbawa are children of elementary school 


\section{Demi Ade Maulana et./al Traditional Games as Tourism Sports and Characteristics of Sports Culture in Sumbawa Indonesia}

age, ie at the age of about 6 to 12 years. The role of the jockey in the game of playing jaran itself is very important, because a jockey plays a role in controlling and spurring their horse as fast as possible and becoming the champion. Even though they are only equipped with makeshift equipment, the little jockeys are required to be trained and understand how to hold on properly to the body. horses, as well as how to maintain balance when a horse is whipped and starts galloping.

The game of playing jaran is said to have existed in the Sumbawa area since the Dutch colonial era. At that time, the playing field was still carried out in ordinary fields and was not a special arena. The participants can be anyone as long as they have a horse that is ready to compete for speed. The attributes used by both the horse and the jockey are still very simple and do not pay attention to the safety and security factors. The difference between playing jaran in the Dutch colonial era and now, the rules of the game at that time did not exist, for those who had a large horse and were ready to compete for speed it was the one who appeared, and the arena was in a field where no special arena was made. Likewise, the attributes used by horses and jockeys are very simple who still do not pay attention to the safety of the horse and jockey.

However, along with the times, playing jaran also experienced changes. The game has shifted from a game to just playing into a competitive game. Consequently, of course, the game becomes more complex with the addition of certain rules for the racehorse and the jockey. This makes playing jaran finally become an event to show achievement and prestige which at the same time provides economic value for the Sumbawa people themselves, because the winning horses, the selling price soars, it can even reach tens or even hundreds of millions of rupiah.

The difference between playing jaran in the Dutch colonial era and now, the rules of the game at that time did not exist, for those who had a large horse and were ready to compete for speed it was the one who appeared, and the arena was in a field where no special arena was made. Likewise, the attributes used by horses and jockeys are very simple who still do not pay attention to the safety of the horse and jockey. We still see this thing done by the people of Sumbawa.

The tradition of playing Jaran is still carried out regularly every year by the Sumbawa people because it is believed to have a function and influence on the social life of the community. By adjusting the provisions of the competition in accordance with the regulations set by the All-Indonesian Equestrian Sports Association Organization (Pordasi), it is hoped that gradually Main Jaran can become the pride of the Sumbawa people.

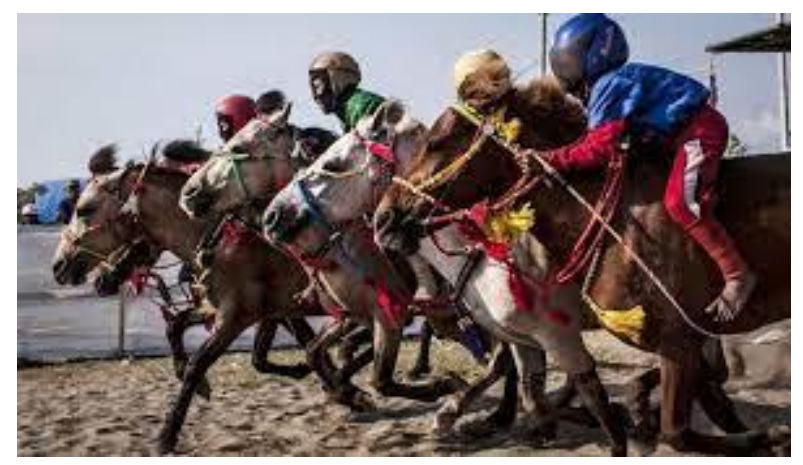

Figure 1. Main jaran event

\section{Main Jaran as a tourism sport and sport culture in Sumbawa}

The difference between playing jaran in the Dutch colonial era and now, the rules of the game at that time did not exist, for those who had a large horse and were ready to compete for speed it was the one who appeared, and the arena was in a field where no special arena was made. In accordance with the times, playing jaran also develops. We still see this thing done by the people of Sumbawa. Judging from the attributes used by the racehorses and the jockeys, they have paid attention to safety. Racehorses are given decorations made of wool and other materials, here are some of the attributes used by racehorses.

a. The attribute jombe is made of rope (wool thread) attached to various kinds of knick-knacks and mounted on the horse's face and neck.

b. Button rope is a rope that is tied and installed in the horse's mouth and is used at the time of release. 


\section{Demi Ade Maulana et./al Traditional Games as Tourism Sports and Characteristics of Sports Culture in Sumbawa Indonesia}

c. Kili is a wire made in the form of a figure eight as a connector for the control rope with the existing chain installed in the horse's mouth.

d. Lapek is a seat for the jockey that is placed on the horse's back and is made of reeds and or dried banana leaves.

Likewise, the attributes used by jockeys are also considered with the aim of maintaining the safety of the jockeys. Here are some of the attributes used by jockeys.

a. Helmet is used as head protection and serves as to reduce injury from jockeys if they fall.

b. Long-sleeved shirt and long pants.

c. The helmet is used as a head covering before wearing a helmet.

d. Whips are usually made of rattan wood.

e. Tire shirt (vest) which has a number as the serial number of the horse.

In addition to the development of the attributes used by the jockeys, the rules for playing the jaran have changed. In the past, the rules of the game were not too strict, but now the rules are very strict. From the racetrack to the rules of the game are very concerned. The rules applied in the game / sport of playing jaran. Starting from the horses, the horses used must be adapted to their respective classes. Here are some classifications of racehorses in Sumbawa jaran main.

a. Puzzles is a class for beginner horses and for the first time doing a race.

b. Teka pas for classes that have participated in the competition 2-3 times.

c. Puzzle A is for experienced horses whose height is $117 \mathrm{~cm}$ to $120 \mathrm{~cm}$.

d. Guess B for a horse that is $121 \mathrm{~cm}$ and above.

e. The OA class is for an old horse that is experienced and has sprung up (four teeth have fallen out) and is $126 \mathrm{~cm}$ tall.

f. Class OB for classes above OA which has a height of $127 \mathrm{~cm}$ to $129 \mathrm{~cm}$.

g. Hope for a horse that has a height of $129 \mathrm{~cm}$ and above and has passed away (four teeth have fallen out).

h. Shoots for horses that have a height of $129 \mathrm{~cm}$ and above and the canines have grown.

i. Adult class.

The techniques that must be followed by the players in following the main jaran. Horses that appear in the competition must register and at the same time take the tire number (releasing box). The jockeys lead their horses to the judges who are in charge of checking the horses and the jockey's readiness to guard against cheating in the race. Horses and jockeys that have undergone inspection go directly to the release box according to the serial number of the tires (release box) obtained from the registration. The horses and jockeys prepared to run as fast as they could after hearing the whistle from the line judges. Like playing football, playing jaran also uses a knockout system in determining the champion. In the first round is called the guger (fall) round, in this round the horse tries to get to the deciding round until it reaches the final round.

Another uniqueness that exists in the karapan race or horse racing or playing jaran is the existence of old. This lawas is the same as in the buffalo race or what is commonly referred to as ngumang, which is a boast of victory as a charmer for female spectators of horse or buffalo races and flirting with the lawas that they master when the horse race takes place. In lawas contained various values and moral messages which are the cultural heritage of the land of Sumbawa. 


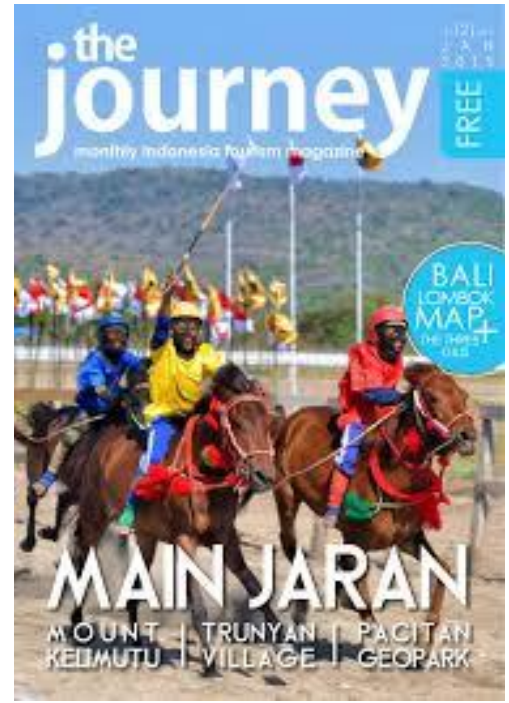

Figure 2. Main jaran event advertising

\section{Excerpts from interviews with community leaders}

"Playing jaran can be used for friendship between citizens, socializing and collaborating."

"Main Jaran also always collaborates with PORDASI as a place to find athlete seeds and also adjust the rules of the game".

From the interview excerpts, it can be developed that sport is a positive medium in developing the values of life and life, one of which is developing social values. In practice, sport requires activities that reflect real life, including life in relation to social values. Playing jaran is a traditional game for the Sumbawa people, apart from being a place to build friendships between the Sumbawa people, playing jaran is also useful for increasing self-confidence, training mental endurance, improving physical abilities, fostering sportsmanship, discipline and tenacity and self-quality for the younger generation who better. The tradition of playing Jaran is still carried out regularly every year by the Sumbawa people because it is believed to have a function and influence on the social life of the community. By adjusting the provisions of the competition in accordance with the regulations set by the All-Indonesian Equestrian Sports Association Organization (Pordasi), it is hoped that gradually Main Jaran can become the pride of the Sumbawa people.

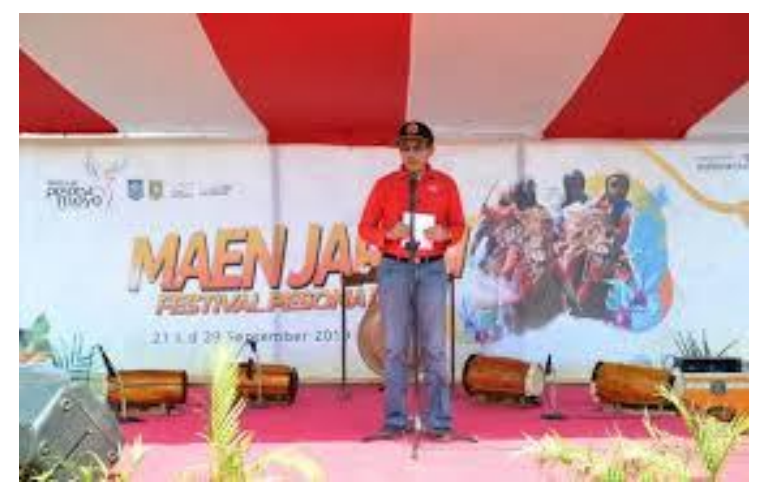

Figure 3. Opening of the main jaran festival

\section{Excerpts from interviews with perpetrators and connoisseurs of playing jaran games}

"The traditional game of playing jaran can develop a brave spirit, teamwork between teams, respect when the team loses, confidence and sportsmanship".

"Every team must have problems experienced, there will be seen the solidity of the team to be able to win. The strength and endurance of the jockey is also tested in the match, in addition to the ability of a quality horse." 


\section{Demi Ade Maulana et./al Traditional Games as Tourism Sports and Characteristics of Sports Culture in Sumbawa Indonesia}

The results of the identification in the excerpts of interviews that have been carried out are related to the sports values contained in the traditional game of playing jaran, namely: cooperation, communication, respecting rules, problem solving, understanding, relationships with others, leadership, respect for others, business values, how to to achieve victory, appreciate defeat, how to manage competence, play fairly, share, self-respect, trust, honesty, confidence, tolerance, and resilience. Ethical values such as fair play, honesty, and sportsmanship have special relevance in sports, where these values can be applied in increasing commitment to implementing fairness in competition.

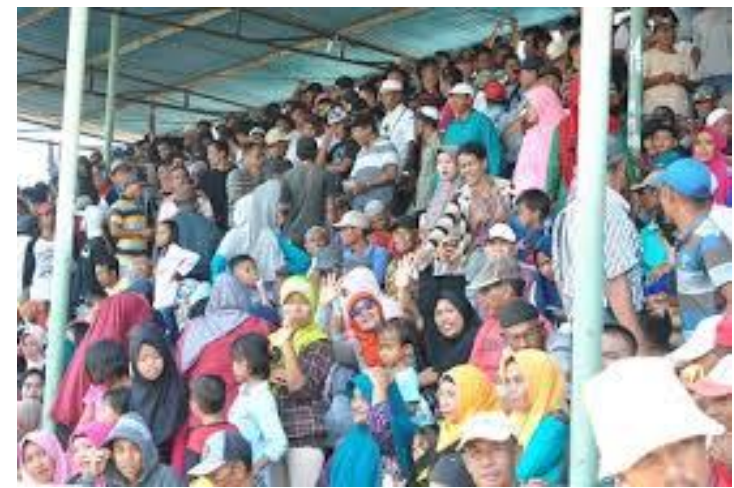

Figure 4. Enjoyment of main jaran events

The values in sports are closely related to the cultural traditions of the community which are passed down from generation to generation. Therefore, sport is a reflection of the social values of a society. As with the results of previous studies, it was found that traditional games have various benefits for children's development, including shaping children's character (Huda, 2018). This study discusses the traditional game of playing jaran found in the Sumbawa area. From the results of the study, it was found that the traditional game of playing jaran is a tradition of the Sumbawa people that developed in the Sumbawa community widely from several centuries ago, the role of the traditional game of playing jaran is not only as an entertainment venue for the Sumbawa people but also as a venue for friendship between the Sumbawa people.

The traditional game of playing jaran is carried out openly and of course by upholding moral values, cooperation values, spiritual values, artistic values, sports values, and also the existing sportsmanship values. As for the tradition of playing jaran games, there are several sports components such as agility, agility, fitness, moral values and sportsmanship.

\section{Conclusion}

Sumbawa is an area rich in culture and tradition, there are many cultures and traditions. One example is in traditional games from the Sumbawa area such as: Barapan kebo, playing Jaran, Bakaraci, gentao, barempuk and so on. In each of these traditional games there is a culture and tradition in each game which is still maintained by the Sumbawa community itself until now. However, although there are many other traditional games, the popularity of the traditional game of Main Jaran is still very popular with the people of Sumbawa until now and is routinely carried out every year on the island of Sumbawa. It can be identified the sports values contained in the traditional game of playing jaran, namely: cooperation, communication, respect for rules, problem solving, understanding, relationships with others, leadership, respect for others, business values, how to achieve victory, respect defeat, how to manage competence, fair play, sharing, self-respect, trust, honesty, confidence, tolerance, and resilience. Ethical values such as fair play, honesty, and sportsmanship have special relevance in sports, where these values can be applied in increasing commitment to implementing fairness in competition.

\section{References}

1. Adi, B. S., Sudaryanti, S., \& Muthmainah, M. (2020). Implementasi permainan tradisional dalam pembelajaran anak usia dini sebagai pembentuk karakter bangsa. Jurnal Pendidikan Anak, 9(1), 33- 


\section{Demi Ade Maulana et./al Traditional Games as Tourism Sports and Characteristics of Sports Culture}

in Sumbawa Indonesia

39. https://doi.org/10.21831/jpa.v9i1.31375

2. Apriliawati, andika tiyas, \& Hartoto, S. (2016). Penerapan Permainan Tradisional Dalam Pembelajaran Pendidikan. Jurnal Pendidikan Olahraga Dan Kesehatan, 4(1), 522-528.

3. Aqobah, Q. J., Ali, M., Decheline, G., \& Raharja, A. T. (2020). Penanaman Perilaku Kerjasama Anak Usia Dini melalui Permainan Tradisional. Jurnal Eksistensi Pendidikan Luar Sekolah, 5(2), 134-142.

4. Artobatama, I. (2019). Pembelajaran Stem Berbasis Outbound Permainan Tradisional. Indonesian Journal of Primary Education, 2(2), 40. https://doi.org/10.17509/ijpe.v2i2.15099

5. Ashar Pajarungi Anar, Dewi, N. K., Maulyda, M. A., \& Nursaptini, N. (2020). Deskripsi Varian Permainan Tradisional Daerah Nusa Tenggara Barat. Progres Pendidikan, 1(3), 273-281. https://doi.org/10.29303/prospek.v1i3.49

6. Burhaein, E. (2017). Aktivitas Permainan Tradisional Berbasis Neurosainslearning Sebagai Pendidikan Karakter Bagi Anak Tunalaras. Jurnal SPORTIF : Jurnal Penelitian Pembelajaran, 3(1), 55. https://doi.org/10.29407/js_unpgri.v3i1.580

7. Danu Iksan, Sahputra Rachmat, W. (2013). Upaya Meningkatkan Teknik Dasar Passing Pada Futsal Dengan Metode Permainan Tradisional Kucing Bola Untuk Siswa Kelas Xi Ips Sma Muhammadiyah Nanga Pinoh. Jurnal Pendidikan Jasmani Kesehatan Dan Rekreasi, 1(1), 59-63.

8. Devrizal, Rini, R., \& Fatmawati, N. (2019). Permainan Tradisional Meningkatkan Kemampuan Motorik Kasar Anak di PAUD Cahaya Kartini Bandar Lampung. JPA - Jurnal Pendidikan Anak, 5(2), 1-10.

9. Hanief, Y. N., \& Sugito, S. (2015). Membentuk Gerak Dasar Pada Siswa Sekolah Dasar Melalui Permainan Tradisional. Jurnal SPORTIF : Jurnal Penelitian Pembelajaran, 1(1), 60-73. https://doi.org/10.29407/js_unpgri.v1i1.575

10. Hayati, H. S., Myrnawati, C., \& Asmawi, M. (2017). Effect of traditional games, learning motivation and learning style on childhoods gross motor skills. International Journal of Education and Research, 5(7), 53-66.

11. Huda, W. N. (2018). Pembentukan Karakter Pada Siswa Sekolah Dasar Melalui Permainan Tradisional. In Prosiding Seminar Nasional "Penguatan Pendidikan Karakter Pada Siswa dalam Menghadapi Tantangan Global (pp. 243-247).

12. Iwandana, D. T., Sugiyanto, \& Hidayatullah, M. F. (2018). Traditional Games to Form Children 's Characters In Dieng Plateau Banjarnegara Central Java Indonesia. Journal of Education, Health and Sport, 8(11), 407-415.

13. Kamaludin, Ngadiman, Festiawan, R., Kusuma, I. J., \& Febriani, A. R. (2020). Pengembangan Permainan Pecah Piring Sintren : Pemanfaatan Olahraga Tradisional Pada Pembelajaran untuk Meningkatkan Kemampuan Motorik Kasar Anak. TEGAR: Journal of Teaching Physical Education in Elementary SchoolJournal of Teaching Physical Education in Elementary School, 3(5), 37-45.

14. Lingling, L. U. W., Rusmana, R., Komarudin, D., \& Gunawan, G. (2019). Peran Permainan Olahraga Tradisional Hadang Terhadap Tingkat Kebugaran Jasmani Siswa. JURNAL SEGAR, 58(12), 7250 7257.

15. Martínez-Santos, R., Founaud, M. P., Aracama, A., \& Oiarbide, A. (2020). Sports Teaching, Traditional Games, and Understanding in Physical Education: A Tale of Two Stories. Frontiers in Psychology, 11(1), 21-29. https://doi.org/10.3389/fpsyg.2020.581721

16. Nugrahastuti, E., Puspitaningtyas, E., \& Puspitasari, M. (2012). Nilai-Nilai Karakter Pada Permainan Tradisional. In Prosiding Seminar Nasional Inovasi Pendidikan Inovasi Pembelajaran Berbasis Karakter dalam Menghadapi Masyarakat Ekonomi ASEAN (pp. 243-247).

17. Nur, M., \& Widiyatmoko, F. A. (2019). Implementasi Permainan Tradisional Untuk Meningkatkan Keaktifan Gerak Siswa. Jendela Olahraga, 4(1). https://doi.org/10.26877/jo.v4i1.3028

18. Nurdiansyah, D. (2018). Pengaruh Permainan Tradisional Hadang Terhadap Agility. JUARA : Jurnal Olahraga, 3(2), 77. https://doi.org/10.33222/juara.v3i2.238

19. Rahayu, E. D., \& Firmansyah, G. (2019). Pengembangan Permainan Tradisional Lompat Tali Untuk Meningkatkan Kinestetic Intelegency Pada Anak Usia 11-12 Tahun. Jendela Olahraga, 4(2), 8. https://doi.org/10.26877/jo.v4i2.3611 


\section{Demi Ade Maulana et./al Traditional Games as Tourism Sports and Characteristics of Sports Culture in Sumbawa Indonesia}

20. Saputra, N. E., \& Ekawati, Y. N. (2017). Permainan Tradisional Meningkatkan Kemampuan Dasar Anak. Jurnal Psikologi Jambi, 2(2), 48-53.

21. Sari, Arum, P. (2017). Permainan Tradisional Egrang Bathok Kelapa Sebagai Potensi Lokal Untuk Kecerdasan Kinestetik Anak Pada Kelompok B di Tk Tunas Rimba I Sumbawa Semarang Tahun Ajaran 2016/2017. Paudia: Jurnal Penelitian Dalam Bidang Pendidikan Anak Usia Dini, 6(1). https://doi.org/10.26877/paudia.v6i1.1861

22. Supeni, S., Ersta, L., Handini, O., \& Yusuf. (2020). Moral values of the javanese traditional game songs to strengthen character education at elementary schools in Surakarta. International Journal of Innovation, Creativity and Change, 12(11), 57-70.

23. Suprayitno. (2014). Peran Permainan Tradisional dalam Membantu Pertumbuhan dan Perkemabngan Gerak Anak Secara menyeluruh. Jurnal Ilmu Keolahragaan, 13(2), 7-15.

24. Syahputra, R., Saifuddin, S., \& Ifwandi, I. (2017). Pengaruh Latihan Olahraga Hadang Terhadap Peningkatan Kebugaran Jasmani Pada Siswa Kelas V SD Negeri 1 Pagar Air. Jurnal Ilmiah Mahasiswa Pendidikan Jasmani, Kesehatan Dan Rekreasi, 3(3), 210-217.

25. Wardika, I. N. (2019). Penerapan Permainan Tradisional untuk mengatasi kejenuhan Belajar PJOK. Journal of Education Action Research, 3(3), 231. https://doi.org/10.23887/jear.v3i3.17377

26. Widodo, P., \& Lumintuarso, R. (2017). Pengembangan model permainan tradisional untuk membangun karakter pada siswa SD kelas atas. Jurnal Keolahragaan, 5(2), 183. https://doi.org/10.21831/jk.v5i2.7215

27. Witasari, O., \& Wiyani, N. A. (2020). Permainan Tradisional untuk Membentuk Karakter Anak Usia Dini. JECED : Journal of Early Childhood Education and Development, 2(1), 52-63. https://doi.org/10.15642/jeced.v2i1.567 